\title{
Plastic Pollution by COVID-19 Pandemic: An Urge for Sustainable Approaches to Protect the Environment
}

\author{
Megha Bansal (iD) and Jai Gopal Sharma* (iD) \\ Department of Biotechnology, Delhi Technological University, Bawana Road, Delhi - 110 042, India.
}

\begin{abstract}
COVID-19 pandemic has created a prolonged impact globally and destructed the life all over the world. The necessary use of personal protective equipments, masks, gloves and other plastic products has to some extent reduced transmission of virus. However, the impact of plastic waste generated worldwide due to the pandemic has affected the environment globally. The coronavirus disease (COVID-19) has destructed and altered every part of life and environment globally. Potential impacts on environment are seen due to the transmission of virus as well as a slowdown in economic activities as lockdown prevails. Increased biomedical waste, improper usage and disposal of surgical masks, disinfectants, gloves, and increasing plastics wastes from domestic households continuously endangers environment. Not only it has an impact on the environment, but also deteriorates human health in the future. Global environmental sustainability is necessitated to overcome the plastic pollution problem and facilitate strategies to recycle and reuse plastics products. This review highlights the influence of COVID-19 on wastes generated by plastic products along with environmental challenges and repercussions. Also, measures to combat the plastic pollution problem have to be implemented for future protection and safety of the environment.
\end{abstract}

Keywords: COVID-19, Deteriorates, Environmental sustainability, Plastic Pollution, Strategies

(C) The Author(s) 2021. Open Access. This article is distributed under the terms of the Creative Commons Attribution 4.0 International License which permits unrestricted use, sharing, distribution, and reproduction in any medium, provided you give appropriate credit to the original author(s) and the source, provide a link to the Creative Commons license, and indicate if changes were made. 


\section{INTRODUCTION}

COVID-19 pandemic, an outbreak originating from Hunan seafood market in China, was considered as an emergency by World Health Organization (WHO) within few months after its origin $^{1}$. COVID-19 popularly referred as (SARSCoV-2), is a contagious and easily transmissible disease causing severe lung infections and acute chronic diseases in individuals $s^{2,3}$. Different studies by researchers have reported the emergence of the virus however significant insights into the immediate source of transmission is not yet configured ${ }^{4}$. As of 14 May, 2021, 160,813,869 confirmed cases and 3,339,002 deaths have been reported by WHO globally ${ }^{5}$. Fig. 1 depicts the prevalence of active cases worldwide as observed by Our World in Data ${ }^{6}$. Studies have reported the transmission of virus via direct contact and through drops formed by cough, sneezing or talk ${ }^{2,7}$. SARSCoV-2 mostly infects the respiratory tract because of over expression of angiotensin-converting enzyme-2 (ACE-2) in epithelial cells. ACE-2 acts as a receptor for attaching to SARS-CoV-2 spike protein ' $S$ ' thereby increasing the chance of infection in humans ${ }^{8}$. Also, emission of $\mathrm{NO}_{2}$ and particulate matter $\left(\mathrm{PM}_{2.5}\right)$ in air increases chance of viral infection as it causes breathing problems in individuals ${ }^{9}$. The common symptoms observed in individuals prone to the virus are fever, body ache, cough, sore throat, breathing problems and even diarrhoea ${ }^{7}$. Acute severe respiratory diseases and mortalities occur in patients that have severe infection of virus ${ }^{7,10}$.

To knock down the epidemic curve, different governments have taken various measures including implementation of partial or complete lockdown ${ }^{11}$, along with treatment facilities to protect the hospital and healthcare workers. Though second highest populous country globally with poor health care systems, India managed to control the transmission of virus by imposing social lockdown at the earliest in

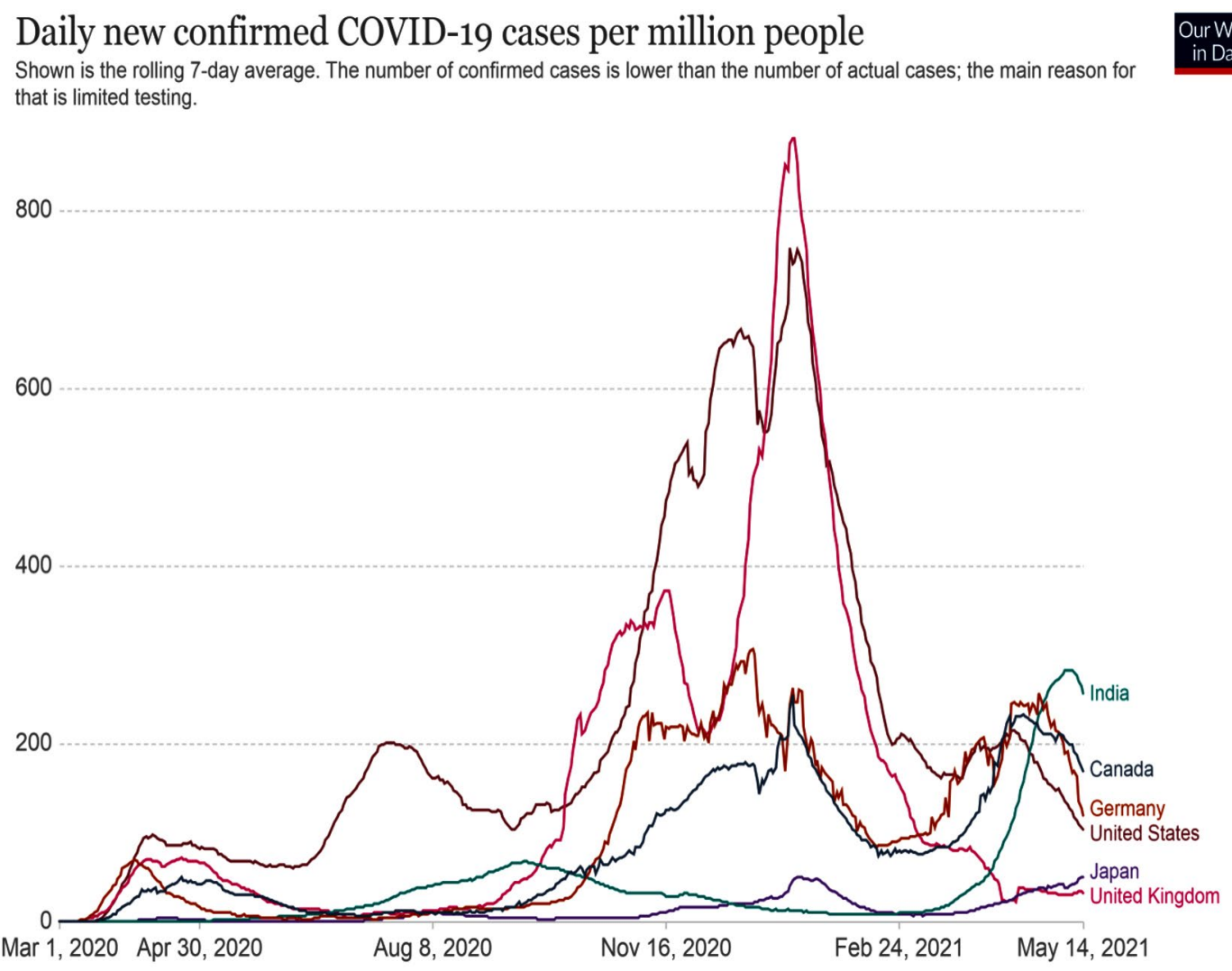

Fig. 1. Confirmed COVID-19 cases globally as on May 14, $2021^{6}$. 
March, $2020^{12}$. It has also initiated the usage of personal protective equipment (PPEs), gloves, surgical masks, sanitizers and plastic packaging to procure and contain the spread of novel coronavirus ${ }^{13,14}$. The major outcome of what started as a health disorder has now become an environmental problem owing to the emerging plastic waste generated from the pandemic and its prevalence in the ecosystem ${ }^{15}$. Various scientists have observed the persistence of COVID-19 virus on plastic surfaces for a longer time that can disrupt the health of individuals and environment ${ }^{3,16}$. The implications posed by the pandemic have been underrated largely on the ecological front and less attention on environmental health problems is paid by governmental agencies ${ }^{17}$.

Unique to the current scenario, this review provides an outlook on deterioration that has occurred due to COVID-19 on management of plastic wastes. The review highlights implications of COVID-19 on plastic production as well as probable consequences of plastic waste generated by COVID-19 on environment. Also the article provides possible strategies and future recommendations to control and manage plastic in post-pandemic era.

Plastic Residues Produced from COVID-19 Tests and their Fate on Environment

Starting the occurrence of COVID-19 virus, several organizations and agencies have recommended the use of prompt plastic products and packaging materials to control transmission of virus. However, scientific community is worried on monitoring and combating plastic waste residues generated by COVID-19 pandemic. Most of the plastic residues are produced from RT-PCR tests of which approximating $97 \%$ of total plastic waste is incinerated to reduce hazardous chemicals from leaching in environment ${ }^{18}$. According to the reports by ${ }^{18}$, around 15439 tonnes of plastic wastes have been generated until August 2020. Globally, the amount of plastic residues from different continents is Asia (9600 tonnes), Europe (2200 tonnes), South America (560 tonnes), North America (2500 tonnes), Africa (270 tonnes) and Oceania (200 tonnes). The countries with most amounts of plastic wastes include China (38\%), Russia (7\%), United States (15\%), India (6.4\%), Germany (1.9\%), Italy (1.6\%), United Kingdom
(3\%), Spain (1.6\%) and Turkey $(1.2 \%)^{18}$. Of all the plastic waste, $90 \%$ contribute to polypropylene, $8 \%$ to polyester and $1.7 \%$ to polyethylene ${ }^{18}$. Different plastic sources identified from COVID-19 tests include plastic swab, falcon tubes, plastic tip, plastic pipettes, buffer plastic bottles, aerosol plastic barrier tips, 96-well PCR plastic plate, and optical plastic plate and eppendorf plastic tubes. Therefore, each test estimates to around $37 \mathrm{~g}$ of plastic residue that is left out in the environment ${ }^{18}$.

In today's scenario, disposal of plastic wastes generated from COVID-19 depends largely on its nature, whether it is classified as biohazardous or non-biohazardous. Biohazardous waste is mostly incinerated emitting various toxic chemicals that pollute the environment ${ }^{19}$ whereas non-biohazardous waste usually ends up in landfill sites thereby being exposed to wild animals and birds. The burning of biohazardous waste also causes air pollution thereby increasing particulate matter in air and increasing the chance of COVID-19 infection and other respiratory disorders ${ }^{8}$. The pollution caused by these plastic residues has many different biological influences in the assemblage specific levels of ecosystem. Plastic residues disintegrating into microplastics affect the marine plants while causing harm to the physical characteristics and soil biota ${ }^{20}$. Especially because of the microplastics small size, the particles could be easily consumed or collected in the brain, or nerves, and also in the circulatory system of the creatures which causes many adverse effects ${ }^{21}$. Sub-deadly impacts include damage of the sensitivity, impairing reproduction capability, damage of mobility, reduced growth and body condition, lack of ability to escape from the predators ${ }^{22}$. Marine mammals like dolphins and whales are known to ingest majority amount of microplastic debris ${ }^{23}$. Many scientists have examined microplastic consumption by microbiota like zooplankton ${ }^{24}$, marine isopod-Idotea emarginata, Calanus helgolandicus; Daphnia magna; Amphipod Orchestoidea tuberculate ${ }^{25}$. Adversative health effects can decrease country's efficiency and waged proficiency with harmful influence on public and economic characteristics. Impacts of COVID-19 Biomedical Waste on Plastic Pollution

Before the emergence of COVID-19 
pandemic, management and control of plastic waste was considered as a major environmental issue owing to disruption in terrestrial and marine environment ${ }^{26,27}$. As plastic waste existing was an undeniable problem, emergence of COVID-19 has threatened the waste management regulatory as well as the environment. Temporary shutdown of restaurants, shopping complexes, stores and other commercial centres have reduced the transmission of the virus but also altered our living habits thereby creating waste management problems ${ }^{28}$. Most of the individuals have shifted to the plastic packaged good including foods, PPE kits, gloves, and face masks along with disposal utensils that have created a havoc in the environment ${ }^{29}$. An increase in online purchase causing more packaged goods and utilization of personal protective equipment (PPE) by hospital staff and health care workers have polluted aquatic environment ${ }^{30}$. A survey in South Korea demonstrated an increase in online food purchasing and daily essentials by around $92 \%$ and $44 \%$ respectively ${ }^{31}$.

The tremendous use of personal protective equipments, including gloves, face masks ${ }^{32}$, and gowns $^{33}$, are usually made of polymeric materials including polypropylene (PP), polyethylene $(P E)^{34}$ and polyethylene terephthalate (PET). These polymeric materials have adverse effects on the terrestrial and aquatic environment ${ }^{35}$. An increase in biomedical waste from different laboratory testing could also account for a substantial proportion of plastic pollution in environment ${ }^{36,37}$. Fig. 2 depicts the plastic waste generation due to COVID-19 pandemic.

Not only does the plastic waste cause pollution to the ecosystem, their fragmentation into smaller microplastics and nanoplastics have detrimental effects on aquatic flora and fauna, soil microorganisms and public ${ }^{38}$. Upon littering into the terrestrial and marine ecosystem, plastic responds differently and causes adverse impact on organisms of specific environment. The plastic waste along with deteriorating the organisms, also causes negative impacts on biodiversity and human health ${ }^{39}$. Moreover, plastic surfaces act as great environment for the growth and proliferation of microorganisms including the COVID-19 virus that could cause infection in large amount of population. Also, plastic littered in open oceans and water bodies act as home for vectors of zoonotic disorders including dengue by Aedes spp. threatening the population ${ }^{40}$. The loss of faith in people due to unpackaged products can cause resurgence of single-use plastics and pollute the environment ${ }^{30}$. Rise in demand of pharmaceutical products including medicines, blister packs, bottles and other products from hospitals and healthcare facilities have drastic impact on plastic waste generation ${ }^{1}$.

\section{Environmental Challenges from COVID-19 Plastic Waste Generation}

Although the COVID-19 pandemic has generated huge tonnes of plastic pollution, but the nationwide lockdown to decrease transmission of virus has also benefitted many sectors that must be highlighted for revival of ecosystem ${ }^{41}$. For instance, following lockdown energy consumption declined considerably in India, China, USA and Italy ${ }^{42}$. Also, drastic reduction in coal and gas consumption was observed in China, Europe, North America and allied countries ${ }^{43}$. Ozone concentrations in atmosphere also increased substantially because of decrease in nitrous oxide contents at ground level ${ }^{44}$. Similarly, lockdown also helped in improving water quality of some Indian rivers including reduction in turbidity, increase in dissolved oxygen and lower levels of biological oxygen demand in river Ganga ${ }^{45}$. Biodiversity and wildlife have benefitted from the lockdown due to reduced exploitation of natural resources by mankind ${ }^{46}$. Despite enormous positive effects on environment created by COVID-19 lockdown, the world still faces disruption owing to plastic pollution. Various international agencies and regulatory authorities have been established to procure and address the detrimental effects of plastic pollution in environment ${ }^{47}$. The perceived threat due to pandemic has undervalued existing plastic pollution problem to a great extent. COVID-19 pandemic has positive and negative consequences on environment as depicted in Table 1.

The plastic litter generated from different usable products as well as personal protective equipments (PPE) gets collected at different sewage drainage systems and dump yards, inducing blockage and percolation along with repercussions on agricultural productivity ${ }^{58}$. Not only are they accumulated by disposal, but also inappropriate environmental conditions including 
wind, storm and water runoff paves way for the biomedical equipments to flow in rivers, streams and lakes ${ }^{59}$. Not only does plastic waste pollute the environment, but the virus adhering to the plastic can mutate and cause transmission to large population affecting the safety of the people ${ }^{60}$. Plastic serves as a vector for spread of pathogenic bacteria and other contaminants that cause detrimental effects on aquatic species and soil microorganisms ${ }^{61}$. Most of the marine organisms mistake the smaller plastic fragments for prey and ingest them as food resulting in toxic effect ${ }^{24}$. Fig. 3 demonstrates possible effects of plastic pollution on environment.

Different plastic waste management processes including incineration generate huge amounts of pollutants released in the atmosphere. These small pollutants mix with the air and cause health hazards to the ecosystem and alter the biodiversity ${ }^{62}$. Moreover, different health disorders such as respiratory diseases, immunological diseases, cancer, and other disorders also cause

Table 1. Negative and positive aspects of COVID-19 on environment

\begin{tabular}{ll}
\hline Positive Effect & Negative Effect \\
\hline Improved outdoor air $^{48}$ & $\begin{array}{l}\text { Decrease in indoor air quality } \\
\text { Less noise pollution }^{50}\end{array}$ \\
$\begin{array}{l}\text { Increase in biomedical waste } \\
\text { Decrease in deforestation }\end{array}$ \\
$\begin{array}{l}\text { Increase ecological risk to environment } \\
\text { Decrease in greenhouse gas emissions }\end{array}$ \\
Less household food waste generation $^{56}$ & $\begin{array}{l}\text { Increase in incineration and land filling } \\
\text { In }\end{array}$ \\
\hline
\end{tabular}

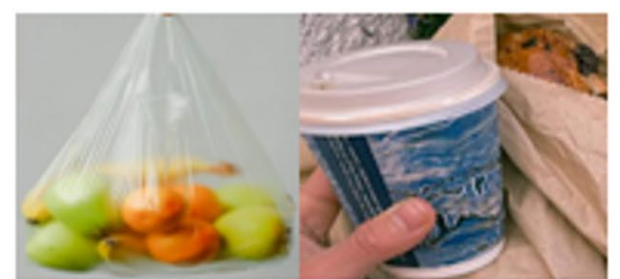

\section{FOOD PACKAGING}

WASTE

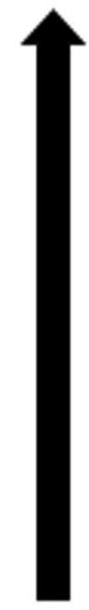

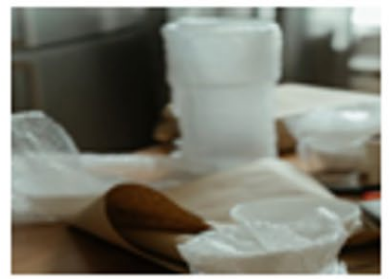

ONLINE PACKAGING PLASTIC BAGS

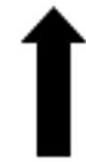

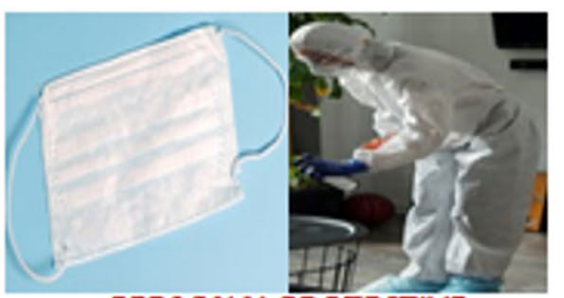

PERSONAL PROTECTIVE

EQUIPMENT

\section{PLASTIC WASTE GENERATION}

Fig. 2. Plastic waste produced from COVID-19 pandemic.

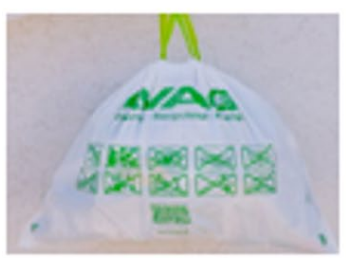

SINGLE USE PLASTICS BAGS

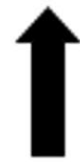

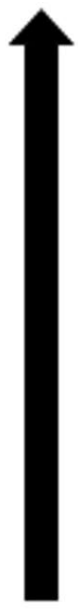


impact on human heath ${ }^{63}$. Exposure of harmful gases in atmosphere by burning of plastic waste causes release of toxic pollutants in soil that cause biological alterations and disrupt the biodiversity ${ }^{64}$. Moreover, different waste recycling activities and management of plastic have come to a halt after the emergence of COVID-19 pandemic ${ }^{55,65}$. Lack of innovation in deferring new management protocols during the pandemic and subsequent increase in plastic pollution has disrupted marine ecosystem, terrestrial environment and agricultural biodiversity. Enforcement of sustainable measures and standard procedures are necessitated to overcome the plastic pollution on a global scale.

\section{Sustainable Measures and Recommendations to} Combat Plastic Waste

COVID-19 pandemic has been prioritised in today's scenario as compared to impact of plastic pollution on environment ${ }^{13}$. The impacts generated by the pandemic should be utilized to build a better future and society by combating plastic pollution ${ }^{66}$. Proper management of plastic waste along with sterilization and disinfection is necessary to contain the spread of transmission and reduce the pollution in the environment. Waste management is important for reducing domestic and medical waste production and require proper guidelines to apply during pandemic to control plastic waste 67. Some plausible measures for sustainability of environment are proposed such as (Fig. 4).

\section{Disinfecting PPE and medical waste}

Treatment of waste using disinfection techniques, including ultraviolet, and ozone utilization can provide a sustainable approach for waste treatment. High amounts of waste necessitate incineration process that uses high temperature to kill pathogenic microbes residing

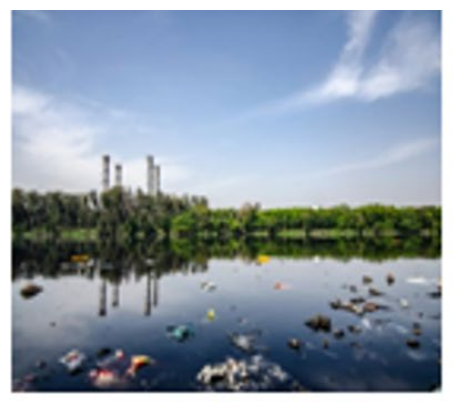

AIR POLLUTION

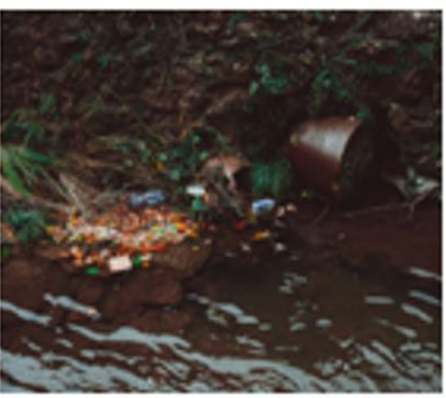

SOIL POLLUTION
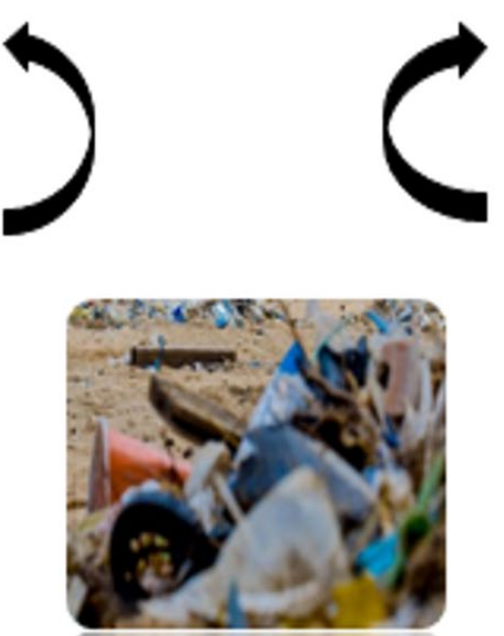

IMPACT OF PLASTIC POLLUTION
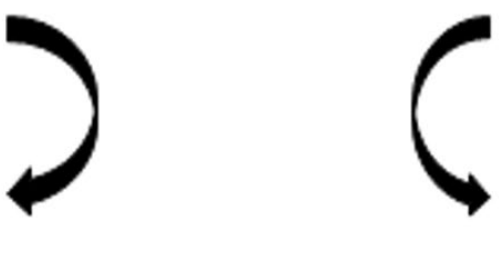

IMPACT ON HUMAN HEALTH

Fig. 3. Impact of plastic pollution on the environment. 
on the surface of plastics. If the amount of waste is less in concentration, chemical disinfectants or high temperature steam is more suitable ${ }^{68}$. Recycling technology could accelerate reuse of PPE kits and reduce the plastic pollution ${ }^{69}$. Various decontamination methods for recycling and reuse of PPE and $\mathrm{N} 95$ masks can be facilitated ${ }^{70}$.

Implementing sustainable safety measures in delivery goods

Proper mitigation strategies while delivery of goods and reusable plastic and grocery bags encourages less waste generation. Paper boxes and cardboard facilitates less emission of plastic waste and also eliminates toxic pollutants from contaminating the environment ${ }^{71}$. Although the utilization of single-use plastic would benefit to contain the spread and transmission of virus, it has an inverse consequence on ecosystem and biodiversity ${ }^{72}$.

\section{Production of bio-based plastics}

The use of various types of plastic products in cosmetics and beauty salons necessitates emerging need for bio-based plastic products ${ }^{73}(p)$. Bio-based plastics have the characteristic ability to reduce carbon footprint and manage waste efficiently thereby decreasing environmental pressure ${ }^{74}$. Overcoming the current limitations posed by the pandemic, transition from petroleum-based plastic to bio-based plastics is a good alternative to reduce plastic pollution and act as environment-friendly alternative ${ }^{75}$.

Synergistic role of government and public

A strong regulatory body approved by government should create awareness on utilization

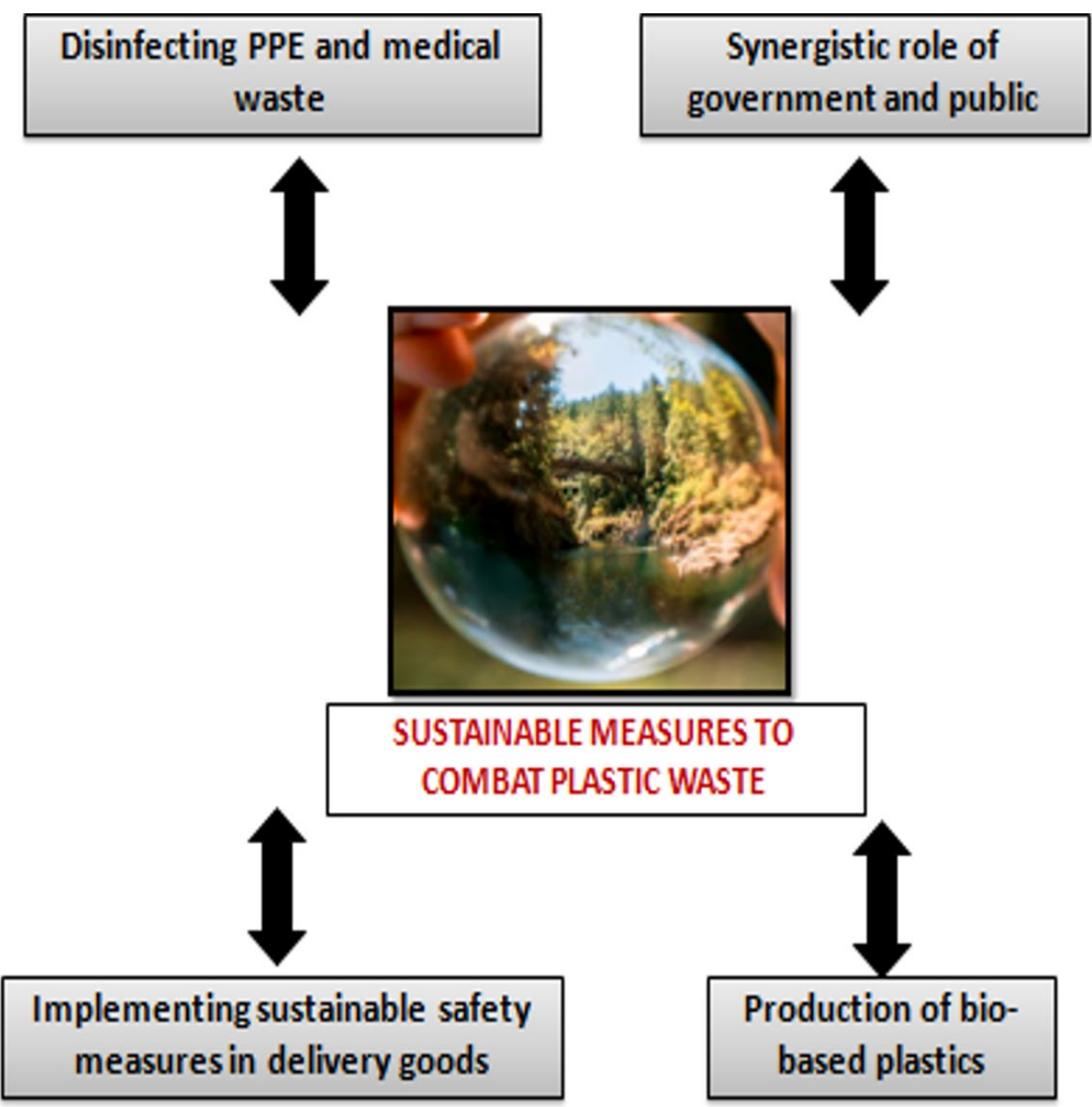

Fig. 4. Sustainable measures to overcome COVID-19 plastic waste problem 
and disposal of plastics waste. Waste that cannot be recycled must be utilized as feedstock or biomass source to create energy ${ }^{67}$. PPE kits and other plastic waste must be sealed in impermeable bags before disposal to have less harmful impact on the environment. Scientific knowledge and evidence is necessary to overcome the ongoing plastic pollution and advance technologies for future.

\section{CONCLUSION}

With the emerging COVID-19 pandemic, the topmost priority by all the people relies on their health and safety. However, the implications and its impacts in long run are undervalued by government and people worldwide. The physical impact of COVID-19 due to plastic generated has harmful consequences on the ecosystem. The use of plastic products might reduce the transmission of virus but could have detrimental effects on the marine environment and agricultural ecosystem post the pandemic. Not only plastic causes pollution, it takes many years to degrade and breaks into smaller fragments of microplastics and nanoplastics. These plastic pieces after inhalation by organisms can cause negative effects on aquatic flora and fauna. For example, latex gloves, entanglement by face masks and surgical plastics products could cause severe injuries to turtles, fishes, whales and other marine organisms. Rethinking and redesigning of PPE kits and plastic products is necessitated to overcome the plastic waste pollution. Improvements in recycling procedures to ensure sustainable use and improve air and water quality are recommended.

\section{ACKNOWLEDGMENTS}

The authors are thankful to the Department of Biotechnology, Delhi Technological University, for providing the facility and infrastructure to carry out the work.

\section{CONFLICT OF INTEREST}

The authors declare that there is no conflict of interests.

\section{AUTHORS' CONTRIBUTION}

Both the authors have made a substantial, direct and intellectual contribution to the work, and approved it for publication.

\section{FUNDING}

None.

\section{DATA AVAILABILITY}

All datasets generated or analyzed during this study are included in the manuscript.

\section{ETHICS STATEMENT}

Not applicable.

\section{REFERENCES}

1. Ramteke S, Sahu BL. Novel coronavirus disease 2019 (COVID-19) pandemic: Considerations for the biomedical waste sector in India. Case Studies in Chemical and Environmental Engineering. 2020;2:100029. doi: 10.1016/j.cscee.2020.100029

2. Islam SMD-U, Bodrud-Doza Md, Khan RM, Haque MdA, Mamun MA. Exploring COVID-19 stress and its factors in Bangladesh: A perception-based study. Heliyon. 2020;6(7):e04399. doi: 10.1016/j.heliyon.2020. e04399

3. Nghiem LD, Morgan B, Donner E, Short MD. The COVID-19 pandemic: Considerations for the waste and wastewater services sector. Case Studies in Chemical and Environmental Engineering. 2020;1:100006. doi: 10.1016/j.cscee.2020.100006

4. Hui DS, I Azhar E, Madani TA, et al. The continuing 2019nCoV epidemic threat of novel coronaviruses to global health - The latest 2019 novel coronavirus outbreak in Wuhan, China. Int J Infect Dis. 2020;91:264-266. doi: 10.1016/j.ijid.2020.01.009

5. WHO Coronavirus (COVID-19) Dashboard. Accessed May 15, 2021. https://covid19.who.int

6. Ritchie H, Ortiz-Ospina E, Beltekian D, et al. Coronavirus Pandemic (COVID-19). Our World in Data. Published online March 5, 2020. Accessed May 15, 2021. https:// ourworldindata.org/coronavirus

7. Wang C, Pan R, Wan X, et al. Immediate Psychological Responses and Associated Factors during the Initial Stage of the 2019 Coronavirus Disease (COVID-19) Epidemic among the General Population in China. Int J Environ Res Public Health. 2020;17(5):1729. doi: 10.3390/ijerph17051729

8. Paital B, Agrawal PK. Air pollution by $\mathrm{NO}_{2}$ and $\mathrm{PM}_{2.5}$ explains COVID-19 infection severity by overexpression of angiotensin-converting enzyme 2 in respiratory cells: a review. Environ Chem Lett. 2020:1-18. doi: 10.1007/s10311-020-01091-w

9. Institute HE. State of Global Air 2019: Air pollution a significant risk factor worldwide. Health Effects Institute. 2019. Accessed July 22, 2021. https://www. healtheffects.org/announcements/state-global-air2019-air-pollution-significant-risk-factor-worldwide

10. Holshue ML, DeBolt C, Lindquist S, et al. First Case of 2019 Novel Coronavirus in the United States. N Engl J Med. 2020;382(10):929-936. doi: 10.1056/ NEJMoa2001191

11. Tobias A. Evaluation of the lockdowns for the SARSCoV-2 epidemic in Italy and Spain after one month 
follow up. Sci Total Environ. 2020;725:138539. doi: 10.1016/j.scitotenv.2020.138539

12. Paital B, Das K, Parida SK. Inter nation social lockdown versus medical care against COVID-19, a mild environmental insight with special reference to India. Sci Total Environ. 2020;728:138914. doi: 10.1016/j. scitotenv.2020.138914

13. Benson NU, Bassey DE, Palanisami T. COVID pollution: impact of COVID-19 pandemic on global plastic waste footprint. Heliyon. 2021;7(2):e06343. doi: 10.1016/j. heliyon.2021.e06343

14. Paterlini M. On the front lines of coronavirus: the Italian response to covid-19. BMJ. 2020;368:m1065. doi: 10.1136/bmj.m1065

15. Singh N, Tang Y, Ogunseitan OA. Environmentally Sustainable Management of Used Personal Protective Equipment. Environ Sci Technol. 2020;54(14):85008502. doi: 10.1021/acs.est.0c03022

16. Chin AWH, Chu JTS, Perera MRA, et al. Stability of SARSCoV-2 in different environmental conditions. medRxiv. 2020. doi: $10.1101 / 2020.03 .15 .20036673$

17. Patricio Silva AL, Prata JC, Walker TR, et al. Rethinking and optimising plastic waste management under COVID-19 pandemic: Policy solutions based on redesign and reduction of single-use plastics and personal protective equipment. Sci Total Environ. 2020;742:140565. doi: 10.1016/j.scitotenv.2020.140565

18. Celis JE, Espejo W, Paredes-Osses E, Contreras SA, Chiang G, Bahamonde P. Plastic residues produced with confirmatory testing for COVID-19: Classification, quantification, fate, and impacts on human health. Sci Total Environ. 2021;760:144167. doi: 10.1016/j. scitotenv.2020.144167

19. Tait PW, Brew J, Che A, et al. The health impacts of waste incineration: a systematic review. Australian and New Zealand Journal of Public Health. 2020;44(1):4048. doi: 10.1111/1753-6405.12939

20. Boots B, Russell CW, Green DS. Effects of Microplastics in Soil Ecosystems: Above and Below Ground. Environ Sci Technol. 2019;53(19):11496-11506. doi: 10.1021/ acs.est.9b03304

21. Bouwmeester H, Hollman PCH, Peters RJB. Potential Health Impact of Environmentally Released Micro- and Nanoplastics in the Human Food Production Chain: Experiences from Nanotoxicology. Environ Sci Technol. 2015;49(15):8932-8947. doi: 10.1021/acs.est.5b01090

22. Zhu D, Bi Q-F, Xiang Q, et al. Trophic predator-prey relationships promote transport of microplastics compared with the single Hypoaspis aculeifer and Folsomia candida. Environ Pollut. 2018;235:150-154. doi: 10.1016/j.envpol.2017.12.058

23. Frasier KE. Evaluating Impacts of Deep Oil Spills on Oceanic Marine Mammals. In: Murawski SA, Ainsworth $\mathrm{CH}$, Gilbert S, et al., eds. Scenarios and Responses to Future Deep Oil Spills: Fighting the Next War. Springer International Publishing; 2020:419-441. doi: 10.1007/978-3-030-12963-7_25

24. Botterell ZLR, Beaumont N, Dorrington T, Steinke $M$, Thompson RC, Lindeque PK. Bioavailability and effects of microplastics on marine zooplankton: A review. Environ Pollut. 2019;245:98-110. doi: 10.1016/j. envpol.2018.10.065
25. Cole M, Lindeque P, Fileman E, Halsband C, Galloway TS. The Impact of Polystyrene Microplastics on Feeding, Function and Fecundity in the Marine Copepod Calanus helgolandicus. Environ Sci Technol. 2015;49(2):1130-1137. doi: 10.1021/es504525u

26. Driedger AGJ, Durr HH, Mitchell K, Van Cappellen P. Plastic debris in the Laurentian Great Lakes: A review. Journal of Great Lakes Research. 2015;41(1):9-19. doi: 10.1016/j.jglr.2014.12.020

27. Krueger MC, Harms H, Schlosser D. Prospects for microbiological solutions to environmental pollution with plastics. Appl Microbiol Biotechnol. 2015;99(21):8857-8874. doi: 10.1007/s00253-0156879-4

28. Higginson R, Jones B, Kerr T, Ridley A-M. Paramedic use of PPE and testing during the COVID-19 pandemic. Journal of Paramedic Practice. 2020;12(6):221-225. doi: 10.12968/jpar.2020.12.6.221

29. Suthar S, Das S, Nagpure A, et al. Epidemiology and diagnosis, environmental resources quality and socioeconomic perspectives for COVID-19 pandemic. $J$ Environ Manage. 2021;280:111700. doi: 10.1016/j. jenvman.2020.111700

30. Xanthos D, Walker TR. International policies to reduce plastic marine pollution from single-use plastics (plastic bags and microbeads): A review. Marine Pollution Bulletin. 2017;118(1):17-26. doi: 10.1016/j. marpolbul.2017.02.048

31. Vanapalli KR, Sharma HB, Ranjan VP, et al. Challenges and strategies for effective plastic waste management during and post COVID-19 pandemic. Sci Total Environ. 2021;750:141514. doi: 10.1016/j. scitotenv.2020.141514

32. Sud SR. COVID-19 and Keeping Clean: A Narrative Review To Ascertain the Efficacy of Personal Protective Equipment To Safeguard Health Care Workers Against SARS-CoV-2. Hospital Pediatrics. 2020;10(7):570-576. doi: 10.1542/hpeds.2020-0135

33. Livingston E, Desai A, Berkwits M. Sourcing Personal Protective Equipment During the COVID-19 Pandemic. JAMA. 2020;323(19):1912-1914. doi: 10.1001/ jama.2020.5317

34. Jung S, Lee S, Dou X, Kwon EE. Valorization of disposable COVID-19 mask through the thermo-chemical process. Chemical Engineering Journal. 2021;405:126658. doi: 10.1016/j.cej.2020.126658

35. Lusher A, Hollman PCH, Mendoza-Hill J. Microplastics in Fisheries and Aquaculture: Status of Knowledge on Their Occurrence and Implications for Aquatic Organisms and Food Safety. Food and Agriculture Organization of the United Nations. 2017.

36. JambeckJR, Geyer R, Wilcox C, et al. Plastic waste inputs from land into the ocean. Science. 2015;347(6223):768771. doi: 10.1126/science.1260352

37. Kane IA, Clare MA, Miramontes E, et al. Seafloor microplastic hotspots controlled by deep-sea circulation. Science. 2020;368(6495):1140-1145. doi: 10.1126/science.aba5899

38. Boyle K, Örmeci B. Microplastics and Nanoplastics in the Freshwater and Terrestrial Environment: A Review. Water. 2020;12(9):2633. doi: 10.3390/w12092633 
39. Monteiro RCP, Ivar do Sul JA, Costa MF. Plastic pollution in islands of the Atlantic Ocean. Environ Pollut. 2018;238:103-110. doi: 10.1016/j.envpol.2018.01.096

40. Saadat S, Rawtani D, Hussain CM. Environmental perspective of COVID-19. Sci Total Environ. 2020;728:138870. doi: 10.1016/j. scitotenv.2020.138870

41. Mousazadeh M, Paital B, Naghdali Z, et al. Positive environmental effects of the coronavirus 2020 episode: a review. Environ Dev Sustain. 2021:1-23. doi: 10.1007/s10668-021-01240-3

42. Year-on-year change in weekly electricity demand, weather corrected, in selected countries, JanuaryDecember 2020 - Charts - Data \& Statistics. IEA. Accessed July 22, 2021. https://www.iea.org/dataand-statistics/charts/year-on-year-change-in-weeklyelectricity-demand-weather-corrected-in-selectedcountries-january-december-2020

43. Nhede N. COVID-19 impacts: Electricity demand and emissions across Europe. Smart Energy International. 2020. Accessed July 22, 2021. https://www. smart-energy.com/industry-sectors/energy-gridmanagement/covid-19-impacts-emissions-acrosseurope-electricity-demand/

44. Sicard P, De Marco A, Agathokleous E, et al. Amplified ozone pollution in cities during the COVID-19 lockdown. Sci Total Environ. 2020;735:139542. doi: 10.1016/j.scitotenv.2020.139542

45. Garg V, Aggarwal SP, Chauhan P. Changes in turbidity along Ganga River using Sentinel-2 satellite data during lockdown associated with COVID-19. Geomatics, Natural Hazards and Risk. 2020;11(1):1175-1195. doi: 10.1080/19475705.2020.1782482

46. Paital B. Nurture to nature via COVID-19, a selfregenerating environmental strategy of environment in global context. Sci Total Environ. 2020;729:139088. doi: 10.1016/j.scitotenv.2020.139088

47. Costa D, Pinto J, Mouneyrac C, Costa M, Duarte AC, Santos TR. The role of legislation, regulatory initiatives and guidelines on the control of plastic pollution. Frontiers in Environmental Science. 2020;8:104.

48. Muhammad S, Long X, Salman M. COVID-19 pandemic and environmental pollution: A blessing in disguise? Sci Total Environ. 2020;728:138820. doi: 10.1016/j. scitotenv.2020.138820

49. Faridi S, Niazi S, Sadeghi K, et al. A field indoor air measurement of SARS-CoV-2 in the patient rooms of the largest hospital in Iran. Sci Total Environ. 2020;725:138401. doi: 10.1016/j. scitotenv.2020.138401

50. Virghileanu M, Savulescu I, Mihai B-A, Nistor C, Dobre R. Nitrogen Dioxide $\left(\mathrm{NO}_{2}\right.$ ) Pollution Monitoring with Sentinel-5P Satellite Imagery over Europe during the Coronavirus Pandemic Outbreak. Remote Sensing. 2020;12(21):3575. doi: 10.3390/rs12213575

51. Tran TT, Pham LT, Ngo QX. Forecasting epidemic spread of SARS-CoV-2 using ARIMA model (Case study: Iran). Global Journal of Environmental Science and Management. 2020;6(Spl. Issue (Covid-19)):1-10. doi:10.22034/GJESM.2019.06.SI.01

52. Nizetic S. Impact of coronavirus (COVID-19) pandemic on air transport mobility, energy, and environment: A case study. International Journal of Energy Research. 2020;44(13):10953-10961.doi: 10.1002/er.5706

53. Zhang H, Tang W, Chen Y, Yin W. Disinfection threatens aquatic ecosystems. Science. 2020;368(6487):146-147. doi: $10.1126 /$ science.abb8905

54. Wang Q, Su M. A preliminary assessment of the impact of COVID-19 on environment - A case study of China. Sci Total Environ. 2020;728:138915. doi: 10.1016/j. scitotenv.2020.138915

55. Zambrano-Monserrate MA, Ruano MA, SanchezAlcalde L. Indirect effects of COVID-19 on the environment. SciTotal Environ. 2020;728:138813. doi: 10.1016/j.scitotenv.2020.138813

56. Jribi S, Ben Ismail H, Doggui D, Debbabi H. COVID-19 virus outbreak lockdown: What impacts on household food wastage? Environ Dev Sustain. 2020;22(5):39393955. doi: 10.1007/s10668-020-00740-y

57. Wang J, Shen J, Ye D, et al. Disinfection technology of hospital wastes and wastewater: Suggestions for disinfection strategy during coronavirus Disease 2019 (COVID-19) pandemic in China. Environ Pollut. 2020;262:114665. doi: 10.1016/j.envpol.2020.114665

58. Corradini F, Meza P, Eguiluz R, Casado F, Huerta-Lwanga $\mathrm{E}$, Geissen V. Evidence of microplastic accumulation in agricultural soils from sewage sludge disposal. Sci Total Environ. 2019;671:411-420. doi: 10.1016/j. scitotenv.2019.03.368

59. Benson NU, Fred-Ahmadu OH, Bassey DE, Atayero AA. COVID-19 pandemic and emerging plastic-based personal protective equipment waste pollution and management in Africa. J Environ Chem Eng. 2021;9(3):105222. doi: 10.1016/j.jece.2021.105222

60. Nunez-Delgado A. What do we know about the SARS-CoV-2 coronavirus in the environment? Sci Total Environ. 2020;727:138647. doi: 10.1016/j. scitotenv.2020.138647

61. Hartmann NB, Rist S, Bodin J, et al. Microplastics as vectors for environmental contaminants: Exploring sorption, desorption, and transfer to biota. Integr Environ Assess Manag. 2017;13(3):488-493. doi: 10.1002/ieam.1904

62. Li H-Y, Gao P-P, Ni H-G. Emission characteristics of parent and halogenated PAHs in simulated municipal solid waste incineration. Sci Total Environ. 2019;665:11-17. doi: 10.1016/j.scitotenv.2019.02.002

63. Ferreira AP. Levels of Organochlorines Contaminants on Fish Species from Coastal Area in the Southeastern Brazil. International Journal of Marine Science. 2013;3:201-211. Accessed April 16, 2021. http://www. aquapublisher.com/index.php/ijms/article/view/825

64. Newman MC. Fundamentals of Ecotoxicology. CRC Press. 2009. doi: 10.1201/9781439883129

65. Somani M, Srivastava AN, Gummadivalli SK, Sharma A. Indirect implications of COVID-19 towards sustainable environment: An investigation in Indian context. Bioresource Technology Reports. 2020;11:100491. doi: 10.1016/j.biteb.2020.100491

66. Prata JC, Silva ALP, Walker TR, Duarte AC, RochaSantos T. COVID-19 Pandemic Repercussions on the Use and Management of Plastics. Environ Sci Technol. 2020;54(13):7760-7765. doi: 10.1021/acs.est.0c02178 67. Prata JC, Silva ALP, da Costa JP, et al. Solutions and 
Integrated Strategies for the Control and Mitigation of Plastic and Microplastic Pollution. International J Environ Res Public Health. 2019;16(13):2411. doi: 10.3390/ijerph16132411

68. Gertsman S, Agarwal A, O'Hearn K, et al. Microwaveand heat-based decontamination of $\mathrm{N} 95$ filtering facepiece respirators: a systematic review. Journal of Hospital Infection. 2020;106(3):536-553. doi: 10.1016/j.jhin.2020.08.016

69. Yalcin I, Sadikoglu TG, Berkalp OB, Bakkal M. Utilization of various non-woven waste forms as reinforcement in polymeric composites. Textile Research Journal. 2013;83(15):1551-1562. doi: 10.1177/0040517512474366

70. Eloise Torres A, B. Lyons A, Narla S, et al. Ultraviolet-C and other methods of decontamination of filtering facepiece $\mathrm{N}-95$ respirators during the COVID-19 pandemic. Photochem Photobiol Sci. 2020;19(6):746751. doi: 10.1039/DOPP00131G

71. Patricio Silva AL, Prata JC, Walker TR, et al. Increased plastic pollution due to COVID-19 pandemic: Challenges and recommendations. Chem Eng J. 2021;405:126683. doi: 10.1016/j.cej.2020.126683

72. Kasidoni M, Moustakas K, Malamis D. The existing situation and challenges regarding the use of plastic carrier bags in Europe. Waste Manag Res. 2015;33(5):419-428. doi: 10.1177/0734242X15577858

73. Napper IE, Thompson RC. Environmental Deterioration of Biodegradable, Oxo-biodegradable, Compostable, and Conventional Plastic Carrier Bags in the Sea, Soil, and Open-Air Over a 3-Year Period. Environ Sci Technol. 2019;53(9):4775-4783. doi: 10.1021/acs.est.8b06984

74. Lambert S, Wagner M. Environmental performance of bio-based and biodegradable plastics: the road ahead. Chem Soc Rev. 2017;46(22):6855-6871. doi: 10.1039/ C7CS00149E

75. Hatti-Kaul R, Nilsson LJ, Zhang B, Rehnberg N, Lundmark S. Designing Biobased Recyclable Polymers for Plastics. Trends Biotechnol. 2020;38(1):50-67. doi: 10.1016/j.tibtech.2019.04.011 